ISSN: 2146-3042

DOI: $10.25095 /$ mufad.756280

\title{
Finansal Okuryazarlık Ve Siirt Üniversitesi Öğrencilerine Yönelik Bir Araştırma*
}

\begin{abstract}
$\ddot{O Z Z E T}$
Kapitalist ekonomik sistemin baskin olduğu günümüz dünyasinda bireylerin belirli bir finansal okuryazarlı düzeyine sahip olması kaçınılmaz olmuştur. Bireylerin finansal bilgi düzeylerini artırması, sağllkl finansal kararlar almalarını ve doğru finansal araçlara yönelmelerini kolaylaştıracaktır. Özellikle 2008 yılında başlayan küresel ekonomik krizden sonra finansal okuryazarliğın önemi dünya çapinda daha fazla vurgulanmaya başlanmıştır. Bu çalış̧mada Siirt Üniversitesi İktisadi ve İdari Bilimler Fakültesi ögrencilerinin finansal okuryazarlk düzeyinin belirlenmesi ve demografik özellikler açısından anlamlı bir farklllı̆ı̆ olup olmadı̆̆ının tespiti için bir araştırma yapılmıştır. Araş̧tırma sonucunda ögrencilerin genel finansal okuryazarlık düzeyinin orta düzeyde olduğu belirlenmiştir. Öğrencilerin yaşları ve ögrrenim gördükleri sinıfları yükseldikçe finansal okuryazarlık düzeylerinin de arttığı tespit edilmiştir. Ayrıca internet bankactlı̆̆ kullanan öğrencilerin kullanmayan ögrencilere göre daha yüksek bir finansal okuryazarlık düzeyine sahip olduğu, diğer demografik özellikler açısından anlamlı bir farklılı̆̆ın olmadığı belirlenmiştir.
\end{abstract}

Anahtar Kelimeler: Finansal Okuryazarlık, Finansal Bilgi, Üniversite Öğrencileri.

JEL Sinıflandırması: A20, D14, J11.

\section{Finacial Literacy And A Study On Siirt Untversity Students}

\section{ABSTRACT}

It is now inevitable for individuals to have a specific level of financial literacy in today's world, where the capitalist economic system is predominant. The increasing financial knowledge levels of individuals will make it easier for them to take healthy financial decisions and tend to correct financial instruments. The importance of financial literacy is now emphasized much more globally, especially after the 2008 global economic crisis. This research is run to determine the financial literacy level of Siirt University Faculty of Economics and Administrative Sciences students and to investigate whether there existed a meaningful difference in terms of demographic characteristics. As a result of the study, it is determined that students have a moderate level of general financial literacy. Also, it is found that, students' financial literacy levels increase parallel to their highering ages and classes. Furthermore, it is detected that students who use online banking have higher financial literacy compared to students who don't use online banking. A meaningful difference is not observed in terms of other demographic characteristics.

Keywords: Financial Literacy, Financial Knowledge, University Students

Jel Classification: A20, D14, J11.

* Makale Gönderim Tarihi: 05.08.2019, Makale Kabul Tarihi: 07.11.2019, Makale Türü: Nicel Araştırma

* Doç.Dr., Ondokuz Mayıs Üniversitesi, Turizm Fakültesi, eyilmaz@omu.edu.tr, ORCID ID: 0000-00022491-446X.

** Dr. Öğr. Üyesi, Siirt Üniversitesi, İktisadi ve İdari Bilimler Fakültesi, tunay_aslan@ @otmail.com, ORCID ID: 0000-0002-0363-6691. 


\section{GíRiş}

Liberal kapitalist ekonomik sistemin günümüz dünyasında baskın sistem olması, kişilerin belirli bir finansal okuryazarlık düzeyine sahip olmasını da gerekli kılmaktadır. Parayı yönetme becerisi günümüzde önemli bir yetenek haline gelmiştir. Modern toplumda insanların, piyasalarda kullanılan finansal araç/ hizmetlerin artan karmaşıklığı ile başa çıkabilmesi ve hayatta kalabilmesi için finansal okuryazarlık becerilerini geliştirmesi zorunluluk haline gelmiştir. Finansal okuryazarlık yetkinliğine sahip olmak, bireylerin karşılaştıkları finansal sorunları çözmek ve bu sorunları önceden öngörüp kaçınmak için oldukça önemlidir. Günümüzde bireylerin refah içinde, mutlu ve sağlıklı bir hayat sürdürmesi için iyi bir finansal okuryazarlık becerisine sahip olması gerekmektedir (Öztürk ve Demir, 2015: 113).

Finansal okuryazarlıkla ilgili tam bir fikir birliğine varılamamakla birlikte, bu konuda, Ekonomik Kalkınma ve İşbirliği Örgütü önemli araştırmalarda ve faaliyetlerde bulunmaktadır. OECD'ye göre finansal okuryazarlık; "bireylerin ekonomik hayata katılımını sağlamak, bireylerin ve toplumun refahını geliştirmek, bireylerin karşılaştıkları finansal durumlar hakkında etkili kararlar vermesini sağlamak amacıyla çeşitli finansal kavramlar ve riskler hakkında bilgi sahibi olmaları ve bu bilgiyi uygulama becerisi” olarak tanımlanmıştır (Güler ve Tunahan, 2017: 81).

Finansal okuryazarlık; tasarruf, yatırım, bütçeleme, borç alma/verme, sigortalama, gelir- gider dengesi ile ilgili uygulamalar, finansal ürün/hizmetler hakkında bilgi ve becerilerin geliştirilmesi, finansal risk ve firsatların öngörülmesi, iktisadi refahın arttırılması için etkin kararlar verilmesini sağlayan bir süreçtir (Gutnu ve Cihangir, 2015: 416). Bu süreç sadece bireyleri değil toplumun tüm kesimlerini etkileyen önemli bir kavramdır. Bireysel finansal okuryazarlık düzeyinin yüksek olması sadece kişinin kendisi için değil toplumun sosyal refahı için de oldukça önemlidir. Ailede öğrenilen para yönetim becerisi eğitim ve tecrübeyle gelişerek tüm toplumun tüketim alışkanlığını etkilemektedir. Kişilerin verdiği bireysel finansal kararlar toplumsal refahın artmasında etkilidir (Çoşkun, 2016: 2247).

Finansal okuryazarlık, sınırlı imkânlara ve bütçeye sahip bireylerin alacakları finansal kararlarda en yüksek faydayı elde etmek isteyen bireyin sahip olması gereken özelliklerdir. $\mathrm{Bu}$ özellikler finansal piyasaların gelişmesi ve çeşitlilik göstermesi ile daha önemli hale gelmiş̧ir. Bireysel tasarrufların hangi finansal ürünlere yatııılacağı, yatırım alternatifleri arasından en uygun seçimin yapılması ve harcamaların yönetilmesi finansal okuryazarlı̆̆ın gelişimine bağlıdır (Coşkun, 2016: 2248).

Literatürde finansal okuryazarlığın ölçülmesi için yapılan akademik çalışmalarda gerek üniversite öğrencileri üzerinde gerekse bireyler üzerinde çok farklı değişkenler kullanılmaktadır. Bu çalışmada Siirt Üniversitesi İktisadi İdari Bilimler Fakültesinde, işletme, iktisat, maliye bölümünde eğitim gören öğrencilerin finansal okuryazarlık düzeyi ölçülmekte ve bu düzeye etki eden değişkenler incelenmektedir. Buna göre çalışma dört bölümden oluşmaktadır. Çalışmanın giriş bölümünün ardından konuyla ilgili literatür incelemesine yer verilmiş daha sonra araştırma hipotezleri ve araştırma bulguları incelenmiş̧tir. Son olarak bu bulgular doğrultusunda değerlendirmeler yapılmıştır. Çalışmada veri toplama yöntemi olarak anket yöntemi kullanılmıştır. Finansal okuryazarlık alt gruplarına 
ilişkin öğrencilerin puanlarının yüzdeleri ile açıklayıcı değişkenler arasındaki "Bağımsız Örneklem t Testi” ve "Tek Yönlü Varyans Analizi” ile kontrol edilmiştir.

\section{LITERATÜR TARAMASI}

Finansal okuryazarlık ve finansal bilgi düzeyinin ölçülmesine yönelik çok sayıda akademik çalışma mevcuttur. Yapılan akademik çalışmalar incelenen örneklem açısından farklılık göstermesine rağmen genellikle finansal okuryazarlığı etkileyen faktörler ve bu faktörler arasındaki ilişkiler ele alınmıştır. Çalışmanın bu kısmında dünyada ve Türkiye'de finansal okuryazarlıkla ilgili bazı akademik çalışmalara ve bulgulara özet olarak yer verilmiştir.

Danes ve Hira (1987), ABD’deki Lowa State Üniversitesi'nde 323 öğrenci ile yaptıkları anket çalışmalarında erkek öğrencilerin kadın öğrencilere göre daha fazla finansal bilgiye sahip olduklarını ve de finansal okuryazarlık bilgi düzeyinin üst sınıflarda daha yüksek olduğunu tespit etmiştir.

Markovich ve DeVaney (1997), 236 üniversite öğrenci üzerinde yaptıkları çalışmada erkek öğrencilerin kadın öğrencilere göre finansal okuryazarlık bilgi düzeyinin daha yüksek olduğunu ortaya çıkarmıştır.

Hogart (2002) yaptığı çalışmada, ABD'de yetişkinler üzerinde finansal okuryazarlık durumunu 28 anket sorusu ile test etmiş, daha düşük eğitim ve gelir seviyesine sahip yetişkinlerin finansal bilgi seviyesinin de daha düşük olduğu sonucuna ulaşmıştır.

Chen ve Volpe (2002), çalışmalarında öğrencilerin finansal okuryazarlık düzeyini belirlemek için 924 üniversite öğrencisine anket uygulamışlardır. Sonuçta finansal okuryazarlık konusunda kadın öğrencilerin finansal bilgi ve becerilerinin erkek öğrencilere göre daha az olduğunu tespit etmişler ve bilgi seviyesi az olan öğrencilerin yanlış görüş, tutum sergilediklerini gözlemlemişlerdir.

Beal ve Delpachitra (2002), Avustralya'daki öğrenciler üzerinde yaptıkları finansal okuryazarlık çalışmalarında öğrencilerin finansal konularda fazla yetenekli olmadıklarını ayrıca gelir düzeyi yüksek ve iş deneyimine sahip öğrencilerin diğer öğrencilere kıyasla finansal okuryazarlık düzeylerinin daha yüksek olduğu sonucuna varmışlardır.

Worthington (2006) çalışmasında, logit regresyon modelini kullanarak finansal okuryazarlık düzeyini tespit etmeye çalışmıştır. Sonuçta finansal okuryazarlık bilgi düzeyi çalışmayan kişilerde çalışan kişilere göre daha düşük çıkmıştır.

Lusardi ve Mitcell (2007) çalışmalarında, kişilerin finansal okuryazarlık ve gelecekle ilgili emeklilik planları arasında herhangi bir ilişkinin olup olmadığına dair bir araştırma yapmışlar, iyi seviyede finansal okuryazarlık bilgi düzeyine sahip olan kişilerin emeklilik planlamaları için de yeterli bilgiye sahip oldukları sonucuna varmışlardır.

Lusardi (2008), ABD'deki farklı etnik yapıya sahip bireylerin finansal okuryazarlık düzeyini ölçmek için yaptığı çalışmada Afrika asıllı Amerikalıların, İspanyolların ve kadınların finansal okuryazarlık seviyesinin düşük düzeyde olduğunu tespit etmiştir. Bunun 
yanında bu etnik grupların finansal okuryazarlık seviyesinin düşük olmasının temel nedeninin düşük eğitim seviyesinden kaynaklanabileceğini ileri sürmüştür.

Cole vd. (2008), Endonezya ve Hindistan'daki finansal okuryazarlık düzeyini ölçtükleri çalışmalarında finansal okuryazarlık ile finansal davranışlar arasında anlamlı ilişkiler tespit etmişlerdir.

Tamimi ve Kalli (2009), çalışmalarında Birleşik Arap Emirlikleri’ndeki yatırımcıların finansal okuryazarlık seviyesinin oldukça zayıf olduğunu tespit etmişlerdir.

Roji vd. (2011), bireylerin finansal okuryazarlığını ve borsa bilgilerini ölçmek amacıyla yaptıkları çalışmalarında ankete katılan hane halkının çoğunun temel finansal bilgilere, enflasyon, paranın zaman değeri, bileşik faiz gibi kavramlara hâkim olduğunu tespit etmiş̧lerdir. Ancak katılımcıların bazı temel kavramların dışında; tahvil, hisse senetleri ve faiz oranları arasındaki ilişkiyi ve portföy çeşitlendirmesi ile riskin azaltılmasını bilmedikleri sonucuna varmıştır.

Almenberg ve Soderbergh (2011) tarafindan İsveç’te yapılan finansal okuryazarlık düzeyinin tespitine ilişkin çalışmada, yaşlıların, kadınların ve düşük gelir düzeyindeki kişilerin finansal okuryazarlık düzeyinin düşük olduğu ortaya konmuştur.

Klapper ve Panos (2013) çalışmalarında, Rusya'da ekonomik kriz döneminde düşük seviyedeki finansal okuryazarlık düzeyinin etkilerini araştırmışlardır. Sonuçta borçlanma oranlarının ani bir şekilde yükseldiği ortamda bile çalışma anketine katılan hane halkının sadece \% 41'nin bileşik faiz kavramını bildikleri sonucuna varmışlardır.

Duca ve Kumar (2014), ABD'de hane halkı üzerinde yapmış oldukları çalışmalarında konut kredisi kullanımı ile finansal okuryazarlık arasındaki ilişkiyi araştırmışlardır. Sonuç olarak finansal okuryazarlık düzeyinin zayıf olduğu ailelerin konut kredisi kullanmaya çok istekli olmadığı sonucuna varmışlardır.

Finansal okuryazarlık ile ilgili Türkiye'de benzer çalışmalara rastlamak mümkündür. Sarıgül (2014), üniversite öğrencilerinin finansal okuryazarlık düzeyinin tespiti ve sosyokültürel özellikler ile finansal okuryazarlık düzeyi arasında anlamlı ilişkinin varlığını araştırmıştır. Bulgular varyans ve regresyon analizi kullanılarak incelenmiştir. Araştırma sonucunda sosyo-kültürel özellikler ile finansal okuryazarlık düzeyi arasında anlamlı ilişki saptanmıştır.

Bayram (2014), üniversite öğrencilerinin finansal okuryazarlık düzeyini belirlemeye çalışmıştır. Sonuç olarak öğrencilerin finansal durumlarını yönetmede kendilerini olduğundan daha başarılı gördüğü sonucuna varmıştır.

Er vd. (2014), üniversite lisans eğitim içeriğinin finansal okuryazarlı̆ga etkisini araştırmışlardır. Çalışma finansal okuryazarlı̆̆ın eğitim programıyla kazanılan bir yetenek olması varsayımı üzerine kurulmuştur. Çalışmada finans dersleri alan öğrencilerin diğer bölümlerdeki bu dersi almamış öğrencilere göre finansal okuryazarlık seviyesinin daha yüksek olduğu sonucuna varmışlardır. 
Ertürk ve Demir (2015), Süleyman Demirel Üniversitesi'nde çalışan akademik personelin finansal bilgi seviyesinin tespitine yönelik bir araştırma yapmışlardır. Sonuç olarak üniversite personelinin finansal konularda bilgi düzeyinin iyi olduğunu fakat finansal eğitime ihtiyaç duyduklarını saptamışlardır.

Fettahoğlu (2015), yaptığı çalışmada Kocaeli'nde ikamet eden ve tesadüfü olarak seçilen bireylerin anket yöntemiyle finansal okuryazarlık düzeyini belirlemeye çalışmış ayrıca hane halkının aile bütçesini yönetmede bilgi ve davranışlarını araştırmıştır. Sonuçta ankete katılan bireylerin temel seviyede finansal okuryazar oldukları ancak karmaşık ve bilgi gerektiren finansal araçlar konusunda yeterince bilgiye sahip olmadıkları sonucuna varmıştır.

Alkaya ve Yağlı (2015), Nevşehir Hacı Bektaş Üniversitesi iktisadi ve idari bilimler fakültesindeki öğrencilerinin finansal bilgi, tutum ve davranışlarını araştırmışlardır. Yapılan analiz sonucunda finansal tutum ve finansal davranış arasında ilişki olduğunu ve öğrencilerin olumlu finansal davranış ve tutum sergilediklerini, fakat öğrencilerin finansal bilgilerinin yeterli düzeyde olmadığını saptamışlardır.

Kılıç vd. (2015), çalışmalarında Gaziantep Üniversitesi öğrencilerinin finansal okuryazarlık düzeylerini sosyal-kültürel özellikler açısından incelemişlerdir. Sonuçta erkek öğrencilerin finansal okuryazarlık düzeyleri kadın öğrencilere göre daha yüksek çıkmış, öğrencilerin finansal okuryazarlıkla ilgili en çok bilgiye sahip olduklarını alanın bireysel bankacılık olduğu, en düşük bilgiye sahip olduğu alanının ise yatırım konusu olduğu sonucuna varmışlardır.

Gutnu ve Cihangir (2015), Osmaniye Korkut Ata Üniversite personelinin kendilerini finansal konularda yeterli görüp görmedikleri, bazı finansal kavramları bilip bilmedikleri üzerine anket araştırması yapmışlardır. Sonuç olarak katılımcıların çoğunlukla güncel finansal konularla ilgilendikleri ve bazı finansal kavramlara hâkim oldukları sonucuna varmışlardır.

Ergün vd. (2015), Osmaniye Korkut Ata Üniversitesi öğrencilerinin finansal okuryazarlık düzeyleri ve finansal okuryazarlığın demografik özelliklerle ilişkisi olup olmadığını araştırmışlardır. Sonuç olarak öğrencilerin yalnızca temel düzeyde finansal okuryazar oldukları ve demografik özelliklilerin finansal okuryazarlıkla ilişkili olduğu sonucuna varmışlardır.

Çoşkun (2016), çalışmasında Anadolu Üniversitesi ön lisans öğrencilerinin finansal okuryazarlık algılarının finansal davranış ve tutumları üzerindeki etkisini araştırmıştır. Yapılan anket sonucunda öğrencilerin temel finansal okuryazar oldukları ancak değişik sermaye araçları hakkında yeterli bilgiye sahip olmadıklarını saptamıştır.

Şamiloğlu vd. (2016), Kayseri Üniversitesi'ndeki 100 işletme bölümü öğrencisi ve 100 diğer bölüm öğrencilerinin finansal okuryazarlık davranışlarını analiz etmişlerdir. Sonuç olarak işletme öğrencilerinin, diğer bölümlerdeki öğrencilere göre, erkek öğrencilerin de kadın öğrencilere göre daha yüksek düzeyde finansal okuryazar olduğu sonucuna varmışlardır.

Tuna ve Ulu (2016), Sakarya Üniversitesi işletme bölümündeki öğrencilerin finansal okuryazarlık düzeylerinin cinsiyet, yaş, gelir durumu, öğrenim görülen bölüm türüne göre 
farklılık gösterip göstermediğini araştırmışlardır. Sonuç olarak bu faktörlerin finansal okuryazarlıkla anlamlı ilişkisi olduğu sonucuna varmışlardır.

Danışman vd. (2016), üniversite öğrencilerinin finansal okuryazarlık düzeylerini araştırmışlardır. Sonuç olarak ekonomi, finans ve muhasebe derslerini alan üniversite öğrencilerinin asgari ölçüde finansal okuryazar olduklarını tespit etmişlerdir.

Baysa ve Karaca (2016), Tokat'ta banka müşterilerinin finansal okuryazarlıklarının hangi segmentte daha yüksek olduğunu araştırmışlardır. Sonuç olarak tarım segmentinin finansal okuryazarlık seviyesinin ticari segmente göre daha düşük olduğu bulgusuna ulaşmışlardır.

Elmas ve Yılmaz (2016), Ağrı İbrahim Çeçen Üniversitesi, İktisadi ve İdari Bilimler Fakültesi öğrencilerinin finansal okuryazarlık düzeylerini ve finansal okuryazarlığın cinsiyet, yaş, gelir durumuna göre farklılık gösterip göstermediğini araştırmışlardır. Yapılan analiz sonucunda öğrencilerin finansal okuryazarlık düzeylerinin düşük olduğu saptanmıştır.

Dilek vd. (2016), Kastamonu Üniversitesi’nde eğitim gören üniversite öğrencilerinin finansal okuryazarlık düzeyini araştırmışlardır. Sonuçta üniversite öğrencilerin finansal okuryazarlık düzeylerinin yeterli olduğu ancak öğrenmeleri gereken çok şey olduğunu saptamışlardır.

Güler ve Tunahan (2017) çalışmalarında, hane halkının finansal okuryazarlık düzeyi ve demografik özelliklerinin finansal davranışlara etkisini araştırmışlardır. Sonuç olarak hane halkının finansal okuryazarlık düzeyinin düşük olduğunu ve demografik özellikler ile finansal okuryazarlık arasında anlamlı ilişkiler bulunduğunu tespit etmişlerdir.

\section{SIIIRT ÜNIVERSITESİ ÖĞRENCILLERININ FINANSAL OKURYAZARLIK DÜZEYLERININN BELIRLENMESINE YÖNELIKK ARAŞTIRMA}

Çalışmanın bu bölümünde Siirt Üniversitesi İktisadi ve İdari Bilimler Fakültesi’nde kayıtlı öğrencilerin finansal okuryazarlık düzeylerinin belirlenmesi ve katılımcıların demografik özelliklerine göre finansal okuryazarlık düzeylerine ilişkin gerekli analizlerin yapılması için verilerin toplanma yöntemi ve bulgularına yer verilecektir.

\subsection{Araştırmanın Amacı ve Örneklem}

Bu araştırmanın amacı, Siirt Üniversitesi İktisadi ve İdari Bilimler Fakültesi (İ̈BF) öğrencilerinin finansal okuryazarlık düzeyinin tespit edilmesidir. Çeşitli üniversitelerde öğrenim gören öğrencilerin finansal okuryazarlık düzeyinin belirlenmesine yönelik yapılan araştırmalar bulunmasına rağmen, Siirt ve civarı illerde bulunan Üniversitelerde böyle bir araştırmanın yapılmamış olması araştırmanın önemini artırmaktadır.

Araştırmanın hedef kitlesi, Siirt Üniversitesi İ̈BF'de bulunan işletme, iktisat ve maliye bölümü öğrencileridir. Bu amaçla, araştırmanın ana kütlesi bu fakültede kayıtlı 598 öğrencidir. Evren bilindiği için hesaplama şu şekilde yapılmıştır: 
Örneklem hesaplanmasında $n=\frac{\mathrm{N} \mathrm{t}^{2} \mathrm{pq}}{\mathrm{d}^{2}(\mathrm{~N}-1)+\mathrm{t}^{\mathrm{s}} \mathrm{pq}} \quad$ formülünden $\quad$ yararlanılmıştır. Formülde; n:örnek büyüklügünü, p: topluluk tahminini, d: kabul edilebilir tolerans düzeyini, $Z$ : istenilen güven aralığını ifade etmektedir. p parametresi bilinmediğinden, en yüksek değeri veren $(0,5 \times 0,5=0,25)$ değeri kullanılmıştır. Sosyal bilimlerde araştırmacılar tarafından genel kabul görmüş güven aralığının \%95 olmasından dolayı, Z değeri 1.96 olarak esas alındığında araştırmanın örneklem büyüklüğü 234 olarak hesaplanmıştır. Araştırma kapsamında ankete katılan ve analiz edilebilir cevap veren 265 öğrencinin verileri değerlendirilmiştir.

\subsection{Veri Toplama ve Analiz Yöntemi}

Araştırmada veri toplama yöntemi olarak anket yöntemi kullanılmıştır. Anket öğrencilere yüz yüze görüşülerek ve amacı açıklanarak uygulanmıştır. Araştırmada Kılıç, Ata ve Seyrek (2015) tarafından geliştirilen anket formu kullanılmıştır. Anketin kullanılması için yazarlardan gerekli izinler alınmıştır. Anket toplam 38 sorudan ve 7 alt gruptan oluşmaktadır. Anket öğrencilerin finansal bilgilerini ölçmekten ziyade finansal okuryazarlık düzeylerini tespit etmeye yöneliktir. Öğrencilere anketteki sorulara verdikleri her bir doğru cevap için "1 puan", yanlış cevap veya fikir beyan etmedikleri sorular için " 0 puan" verilmiştir. Her bir öğrenci en fazla 38 puan alabilecektir. Her bir alt gruba ilişkin öğrencilerin finansal okuryazarlık puanlarının yüzdeleri ile açıklayıcı değişkenler arasındaki ilişkinin istatistiksel olarak önemli olup olmadığ 1 "Bağımsız Örneklem t Testi” ve "Tek Yönlü Varyans Analizi" ile kontrol edilmiştir. Tek Yönlü Varyans Analizi sonucunda F değeri anlamlı çıkan değişkenlerin gruplarına ilişkin puan yüzdeleri arasındaki farkın anlamlılığı Tukey ile kontrol edilmiş ve sonuçlar tablolar halinde verilmiştir.

\subsection{Araştırmanın Hipotezleri}

Araştırmanın amacı doğrultusunda geliştirilen hipotezler aşağıdaki gibidir:

H1. Öğrencilerin cinsiyetleri ile finansal okuryazarlık düzeyleri arasında anlamlı bir ilişki vardır.

H2. Öğrencilerin yaşları ile finansal okuryazarlık düzeyleri arasında anlamlı bir ilişki vardır

H3. Öğrencilerin öğrenim gördükleri bölüm ile finansal okuryazarlık düzeyleri arasında anlamlı bir ilişki vardır.

H4. Öğrencilerin öğrenim gördükleri sınıf ile finansal okuryazarlık düzeyleri arasında anlamlı bir ilişki vardır.

H5. Internet bankacılı̆̆ı kullanan ögrenciler ile kullanmayan öğrencilerin finansal okuryazarlık düzeyleri arasında anlamlı bir ilişki vardır.

H6. Bireysel emeklilik sitemine kayıtlı olan ögrenciler ile kayıtlı olmayan öğrencilerin finansal okuryazarlı düzeyleri arasında anlamlı bir ilişki vardır. 
H7. Kredi kartı kullanan öğrenciler ile kullanmayan öğrenciler arasında finansal okuryazarlık düzeyleri arasında anlamlı bir ilişki vardır.

\subsection{Bulgular}

Finansal okuryazarlık anketinde yer alan alt grupların açıklayıcı değişkenlerle ilişkisini ortaya koymak için yapılan analiz sonuçları bu bölümde açıklanmıştır.

\subsubsection{Demografik Bulgular}

Öğrencilerin cinsiyeti, fakültesi, sınıfı, anne-baba eğitim düzeyi, kredi kartı ve internet bankacılığı kullanım durumuna göre frekans ve yüzde analizi bilgileri aşağıda Tablo 1'de gösterilmiştir.

Tablo 1. Demografik Özellikler

\begin{tabular}{|c|c|c|c|}
\hline Demografikler & & Frekans (n) & Yüzde (\%) \\
\hline \multirow{3}{*}{ Cinsiyet } & Kadın & 119 & 46 \\
\hline & Erkek & 146 & 54 \\
\hline & Toplam & 265 & $\% 100$ \\
\hline \multirow{4}{*}{ Yaş } & $18-21$ & 84 & 32 \\
\hline & $22-25$ & 150 & 56 \\
\hline & 25 yaş ve üzeri & 31 & 12 \\
\hline & Toplam & 265 & 100 \\
\hline \multirow{4}{*}{ Bölüm } & İşletme & 150 & 58 \\
\hline & İktisat & 38 & 14 \\
\hline & Maliye & 77 & 28 \\
\hline & Toplam & 265 & 100 \\
\hline \multirow{5}{*}{ Sinif } & 1.Sinif & 32 & 12 \\
\hline & 2.Sinif & 64 & 24 \\
\hline & 3.Sinif & 97 & 37 \\
\hline & 4.Sinif & 72 & 27 \\
\hline & Toplam & 265 & 100 \\
\hline \multirow{3}{*}{$\begin{array}{c}\text { İnternet Bankacılığı } \\
\text { Kullanma }\end{array}$} & Evet & 31 & 12 \\
\hline & Hayır & 234 & 88 \\
\hline & Toplam & 265 & 100 \\
\hline \multirow{3}{*}{$\begin{array}{c}\text { Bireysel Emeklilik } \\
\text { Sistemine Kayıtlı } \\
\text { Olma }\end{array}$} & Evet & 31 & 12 \\
\hline & Hayır & 234 & 88 \\
\hline & Toplam & 265 & 100 \\
\hline \multirow{3}{*}{$\begin{array}{l}\text { Kredi Kartı } \\
\text { Kullanma }\end{array}$} & Evet & 160 & 60 \\
\hline & Hayır & 105 & 40 \\
\hline & Toplam & 265 & 100 \\
\hline
\end{tabular}

Araştırmaya katılanların 119'u (\%46) erkek, 146’s1 (\%54) kadın öğrencilerdir. Katılımcıların 150'si (\%58) işletme, 38'i (\%14) iktisat ve 77'si (\%28) maliye bölümünde öğrenim görmektedir. Bu öğrencilerden 32'si (\%12) 1.sınıf, 64'ü (\%24) 2.sınıf, 97'si (\%37) 3.sınıf ve 72'si (\%27) 4. sinıf öğrencisidir. Öğrencilerin anne-baba eğitimlerinin ağırlıklı olarak (\%40) ilköğretim mezunu oldukları görülmektedir. Katılımcılardan 31’i (\%12) en az 
bir bireysel emeklilik sistemine kayıtlı iken 234'ü (\%88) herhangi bir bireysel emeklilik sistemine kayıtlı olmadığını beyan etmiştir. 160 öğrenci (\%60) kredi kartı kullanırken 105 öğrenci (\%40) kredi kartı kullanmamaktadır. 226 öğrenci \%86) internet bankacılığını kullandığını ve 39 öğrenci (\%14) internet bankacılığını kullanmadığını ifade etmiştir.

\subsubsection{Demografik Özelliklere Göre Başarı Puanları}

Anketin ilk yedi bölümündeki sorulara verilen doğru cevaplar sonucunda ortalama başarı puanları oluşturulmuştur. Analiz kısmında yapılan tüm testlerde ortalama başarı yüzdeleri kullanılmıştır. Katılımcıların demografik özelliklerine göre 100 üzerinden hesaplanmış ortalama başarı puanları aşağıda tablo halinde gösterilmiştir.

Tablo 2. Demografik Özelliklere Göre Ortalama Başarı Puanları (100 üzerinden)

\begin{tabular}{|c|c|c|c|c|c|c|c|c|c|c|c|}
\hline & & $\mathbf{N}$ & $\%$ & TEF & BB & ES & FT & $\mathbf{Y}$ & VM & MF & GB \\
\hline $\begin{array}{l}\text { Genel } \\
\text { puanları }\end{array}$ & & 265 & $\% 100$ & 61 & 57 & 53 & 65 & 41 & 52 & 39 & 53 \\
\hline \multirow[t]{2}{*}{ Cinsiyet } & Erkek & 119 & $\% 46$ & 62 & 57 & 52 & 62 & 41 & 53 & 44 & 53 \\
\hline & Kadın & 146 & $\% 54$ & 59 & 56 & 53 & 67 & 30 & 49 & 35 & 51 \\
\hline \multirow[t]{3}{*}{$\overline{\text { Bölüm }}$} & İşletme & 150 & $\% 58$ & 63 & 58 & 51 & 67 & 42 & 50 & 41 & 54 \\
\hline & İktisat & 38 & $\% 14$ & 57 & 53 & 53 & 59 & 45 & 46 & 36 & 50 \\
\hline & Maliye & 77 & $\% 28$ & 58 & 56 & 56 & 64 & 35 & 57 & 37 & 52 \\
\hline \multirow[t]{4}{*}{ Sinıf } & 1.Sinif & 32 & $\% 12$ & 43 & 61 & 49 & 56 & 38 & 45 & 36 & 47 \\
\hline & 2.Sinif & 64 & $\% 24$ & 58 & 55 & 51 & 64 & 33 & 49 & 37 & 50 \\
\hline & 3.Sinif & 97 & $\% 37$ & 62 & 57 & 55 & 66 & 40 & 52 & 38 & 53 \\
\hline & 4.Sinıf & 72 & $\% 27$ & 67 & 57 & 53 & 69 & 49 & 55 & 44 & 57 \\
\hline \multirow[t]{2}{*}{ Bireysel Emeklilik } & Evet & 31 & $\% 12$ & 60 & 60 & 54 & 46 & 46 & 54 & 48 & 54 \\
\hline & Hayır & 234 & $\% 88$ & 60 & 56 & 66 & 40 & 40 & 51 & 51 & 52 \\
\hline$\overline{\text { Kredi Kartı }}$ & Evet & 160 & $\% 60$ & 63 & 58 & 51 & 64 & 42 & 52 & 41 & 54 \\
\hline Kullanımı & Hayır & 105 & $\% 40$ & 57 & 55 & 56 & 67 & 39 & 50 & 36 & 52 \\
\hline \multirow{2}{*}{$\begin{array}{l}\text { İnternet } \\
\text { Bankacıllı̆ı } \\
\text { Kullanımı }\end{array}$} & Evet & 226 & $\% 86$ & 62 & 57 & 53 & 65 & 41 & 52 & 40 & 54 \\
\hline & Hayır & 39 & $\% 14$ & 54 & 56 & 53 & 65 & 37 & 48 & 33 & 49 \\
\hline
\end{tabular}

TEF: Temel Ekonomi ve Finans Başarı Puanı

ES: Emeklilik ve Sigortacılık Başarı Puanı

Y: Yatırım Başarı Puanı

BB: Bireysel Bankacılık Başarı Puanı

FT: Finansal Tablolar Başarı Puanı

VM: Vergi ve Mevzuat Başarı Puanı

MFH: Matematik ve Faiz Hesaplamaları Puanı

GB: Genel Başarı Puanı

Buna göre katılımcıların finansal okuryazarlık konusunda genel başarı oranının \%53 düzeyinde gerçekleştiği tespit edilmiştir. Öğrencilerin anket sorularına verdikleri cevaplar incelendiğinde en yüksek oranda finansal tablolar kategorisinde başarılı oldukları (\%65), en düşük başarı oranının ise matematik ve faiz hesaplamaları kategorisinde olduğu (\%39) görülmektedir.

Cinsiyete göre finansal okuryazarlık düzeyi incelendiğinde erkek öğrencilerin bayan öğrencilerden küçük bir farkla daha başarılı oldukları söylenebilir. Erkek öğrencilerin finansal okuryazarlık düzeyi \%53 iken, bayan öğrencilerin oranı \%51 olmuştur. 
Bölümlere göre inceleme yapıldığında, işletme bölümü öğrencilerinin \% 54 oranla maliye (\%52) ve iktisat (\%50) bölümü ögrencilerden daha başarılı oldukları görülmektedir.

Sınıflar bazında mukayese yapıldığında, 4. sınıf öğrencileri \% 57 oranla en başarılı sınıf olurken, $3 . s ı n ı$ öğrencileri $\% 53$, 2.sınıf öğrencileri $\% 50$ ve 1 .sınıf öğrencilerin de $\% 47$ oranla sinıfları ile orantılı olarak finansal okuryazarlık düzeyine sahip oldukları görülmektedir.

Bireysel emeklilik sistemine kayıtlı öğrencilerin (\%54) kayıtlı olmayan öğrencilerden (\%52) biraz daha yüksek bir finansal okuryazarlık düzeyine sahip olduğu görülürken, aynı durum kredi kullanan ve internet bankacılığı kullanan öğrenciler ile kullanmayan öğrenciler içinde geçerlidir.

\subsection{3. Öğrencilerin Cinsiyetleri ile Finansal Okuryazarlık Düzeyleri Arasındaki İlişkinin İncelenmesi}

Öğrencilerin cinsiyetleri ile finansal okuryazarlık düzeyleri arasında anlamlı bir ilişkinin olup olmadığı Bağımsız Örneklem t Testi ile kontrol edilmiştir. Bağımsız iki örnekten elde edilen nicel ve nitel verilerin istatistikleri kullanılarak test edilmesinde bağımsız örneklem $\mathrm{t}$ testinden yararlanılır. Tablo 3'de $\mathrm{t}$ testinin sonucu gösterilmiştir.

Tablo 3. Öğrencilerin Cinsiyetleri ile Finansal Okuryazarlık Düzeyleri Arasındaki İlişkiye İlişkin t Testi Sonuçları

\begin{tabular}{|c|l|c|c|c|c|c|c|}
\hline Hipotez & \multicolumn{1}{|c|}{ Cinsiyet } & $\mathbf{N}$ & $\overline{\mathbf{X}}$ & $\mathbf{s . s}$ & $\mathbf{t}$ & $\mathbf{p}^{*}$ & $\begin{array}{c}\text { Hipotez } \\
\text { Sonucu }\end{array}$ \\
\hline \multirow{2}{*}{ H1 } & Erkek & 119 & 53 & 13,28 & \multirow{2}{*}{1,368} & \multirow{2}{*}{0,171} & RED \\
\cline { 2 - 5 } & Kadın & 166 & 51 & 11,41 & & & \\
\hline \multicolumn{2}{|c|}{$* \mathrm{p}<0,05 ;$}
\end{tabular}

$\mathrm{N}=$ Gözlem sayıs1, s.s. $=$ Standart Sapma, $\mathrm{t}=$ test istatisiği $\overline{\mathrm{X}}=$ aritmetik ortalama, $\mathrm{p}=$ anlamlll1k düzeyi

Tablo 3 incelendiğinde erkek öğrencilerin başarı düzeyinin bayan öğrencilere daha yüksek olmasına rağmen farklılığın istatistiki olarak anlamlı düzeyde olmadığ $\quad(p>0,05)$ görülmektedir. Buna göre " $H 1$. Ögrrencilerin cinsiyetleri ile finansal okuryazarlık düzeyleri arasında anlamlı bir ilişki vardır." hipotezi reddedilmiştir.

\subsection{4. Öğrencilerin Yaşları ile Finansal Okuryazarlık Düzeyleri Arasındaki İlişsi}

Öğrencilerin finansal okuryazarlık düzeyleri ile yaşları arasında istatistiki olarak anlamlı bir farklılığın olup olmadığı Tek Yönlü Varyans Analizi (ANOVA) ile analiz edilmiştir. Anova (F) testi, normal dağılan bağımsız iki örnekten büyük varyansın küçük varyansa oranlanması ile yapılan bir varyans türdeşlik testidir. F test istatistiği önemli ise örnek varyanslarının türdeş olmadıklarına, değişse türdeş olduklarına karar verilir (Özdamar, 2004:318). Gruplararası kareler ortalaması, gruplar içi kareler ortalamasına bölünerek varyans analizinin test istatistiği olan $\mathrm{F}$ değeri elde edilir. Hesaplanan $\mathrm{F}$ değeri, $\mathrm{F}$ tablosundan elde edilen kritik değerden büyükse örnek ortalamaları arasındaki farklılığın önemli olduğuna, kritik değerden küçükse örnek ortalamaları arasındaki farklılığın önemli olmadığına hükmedilir. Serbestlik derecesi (df) örnek içinde serbestçe değişebilecek gözlem değeri 
sayısını gösterir (Köseoğlu ve Yamak, 2002:54). Tablo 4 ve 5'de ANOVA testinin sonuçları görülmektedir.

Tablo 4. Yaş Değişkenine Göre Finansal Okuryazarlık Düzeylerine İlişkin Betimsel İstatistikler

\begin{tabular}{cccc}
\hline Yaşlar & $\mathbf{N}$ & $\overline{\mathbf{X}}$ & s.s. \\
\hline $18-21$ yaş & 84 & 51,39 & 11,62 \\
$22-25$ yaş & 153 & 52,33 & 12,49 \\
25 yaş üstü & 28 & 59,75 & 11,42 \\
Toplam & $\mathbf{2 6 5}$ & $\mathbf{5 2 , 8 2 2 6}$ & $\mathbf{1 2 , 3 1}$ \\
\hline
\end{tabular}

$\mathrm{N}=$ gözlem sayıs1, $\overline{\mathrm{X}}=$ ortalama, s.s.= standart sapma

Tablo 4 incelendiğinde öğrencilerin yaşları ile finansal okuryazarlık düzeyleri arasında doğru orantı olduğu, yaşları yükseldikçe finansal okuryazarlık düzeylerinin de yükseldiği görülmektedir. Yaş değişkenine göre ortaya çıkan bu farklılığın anlamlı bir fark olup olmadığ ANOVA testi ile test edilmiş ve elde edilen sonuçlar aşağıdaki tabloda da gösterilmiştir.

Tablo 5. Öğrencilerin Yaşları ile Finansal Okuryazarlık Düzeyleri Arasındaki İlişkiye İlişkin ANOVA Testi Sonuçları

\begin{tabular}{cccccc}
\hline & Kareler Toplamı & df & Ortalama Kare & F & p* \\
\hline Gruplar arası & 1551,051 & 2 & 775,526 & 5,283 &, 006 \\
Grup içi & 38461,613 & 262 & 146,800 & & \\
Toplam & 40012,664 & 264 & & & \\
\hline
\end{tabular}

$* \mathrm{p}<0,05, \mathrm{df}=$ serbestlik derecesi, $\mathrm{F}=$ test istatistiği, $\mathrm{p}=$ anlamlılık düzeyi

Yapılan ANOVA testi sonucunda öğrencilerin finansal okuryazarlık düzeyleri ile yaşları arasında istatistiksel olarak anlamlı bir farklılık olduğu tespit edilmiştir $(\mathrm{F}=5,283$, $\mathrm{p}<0,05)$. Bu farklılığın hangi sınıflar arasında olduğunu tespit etmek için Tukey çoklu karşılaştırma testi yapılmış ve sonuçlar Tablo 6'da gösterilmiştir.

Tablo 6. Araştırma Grubunun Yaş Değişkenine Göre Finansal Okuryazarlık Düzeyine İlişkin Tukey Testi Karşılaştırılmasını Gösteren Dağılım

\begin{tabular}{llcc}
\hline Yaş Grupları & Sınıf Değişkenleri & Ortalamalar Farkı & p \\
\hline \multirow{2}{*}{$\mathbf{1 8 - 2 1}$ yaş } & $22-25$ yaş &,- 94701 &, 833 \\
\cline { 2 - 4 } & 25 yaş ve üstü & $-8,35714^{*}$ &, 005 \\
\hline \multirow{2}{*}{$\mathbf{2 2 - 2 5}$ yaş } & $18-21$ yaş &, 94701 &, 833 \\
\cline { 2 - 4 } & 25 yaş ve üstü & $-7,41013^{*}$ &, 009 \\
\hline \multirow{2}{*}{ 25 yaş ve üstü } & $18-21$ yaş & $8,35714^{*}$ &, 005 \\
\cline { 2 - 4 } & $22-25$ yaş & $7,41013^{*}$ &, 009 \\
\hline
\end{tabular}


Tablo 6 incelendiğinde, 25 yaş ve üstü grubu öğrencilerin finansal okuryazarlık düzeyleri hem 18-21 yaş grubundaki öğrencilere göre hem de 22-25 yaş grubundaki öğrencilere göre farklılık göstermekte olduğu, bu farklılığın istatistiki olarak anlamlı düzeyde olduğu görülmektedir. Bu sonuçlara göre "H2. Öğrencilerin yaşları ile finansal okuryazarllk düzeyleri arasında anlamlı bir ilişki vardır" hipotezi kabul edilmiştir.

\subsection{5. Öğrencilerin Bölümleri ile Finansal Okuryazarlık Düzeyleri Arasındaki} İlişki Öğrencilerin öğrenim gördükleri bölümleri açısından finansal okuryazarlık düzeyleri arasında anlamlı bir farklılı̆̆ın olup olmadığı ANOVA testi ile test edilmiş ve test sonuçları Tablo 7 ve 8 'de gösterilmiş̧ir.

Tablo 7. Öğrencilerin Bölümleri ile Finansal Okuryazarlık Düzeyleri Arasındaki İlişkiye İlişkin Betimsel İstatistikler

\begin{tabular}{cccc}
\hline Sinıflar & $\mathbf{N}$ & $\overline{\mathbf{X}}$ & s.s. \\
\hline İşletme & 150 & 53,85 & 12,17 \\
İktisat & 38 & 50,15 & 13,71 \\
Maliye & 77 & 52,16 & 11,75 \\
Toplam & 265 & 52,82 & 12,31 \\
\hline
\end{tabular}

$\mathrm{N}=$ gözlem sayısı, $\overline{\mathrm{X}}=$ ortalama, s.s.= standart sapma

Tablo 7 incelendiğinde, ortalaması en yüksek olan bölümün işletme bölümü $(53,85)$ olduğu, ortalaması en düşük olan bölümün de iktisat bölümü $(50,15)$ olduğu görülmektedir. Bölüm değişkenine göre ortaya çıkan bu farklılığın istatistiki olarak anlamlı bir farklılık olup olmadığına ilişkin yapılan ANOVA test sonuçları aşağıdaki tabloda da gösterilmiştir.

Tablo 8. Öğrencilerin Bölümleri ile Finansal Okuryazarlık Düzeyleri Arasındaki İlişkiye İlişkin ANOVA Testi Sonuçları

\begin{tabular}{cccccc}
\hline & Kareler Toplamı & df & Ortalama Kare & F & p \\
\hline Gruplar aras1 & 459,322 & 2 & 229,661 & 1,521 &, 220 \\
Grup içi & 39553,343 & 262 & 150,967 & & \\
Toplam & 40012,664 & 264 & & & \\
\hline *p $<0,05$ & & & & \\
df $=$ serbestlik derecesi, F= test istatistiği, $\mathrm{p}=$ anlamlılik düzeyi
\end{tabular}

Yapılan ANOVA testi sonucunda öğrencilerin finansal okuryazarlık düzeyleri ile öğrenim gördükleri bölümler arasında ortaya çıkan farklılığın istatistiki olarak anlamlı olmadığı görülmektedir $(\mathrm{F}=1,521, \mathrm{p}>0,05)$.

$\mathrm{Bu}$ sonuçlara göre "H3. Öğrencilerin öğrenim gördükleri bölüm ile finansal okuryazarlık düzeyleri arasında anlamlı bir ilişki vardır” hipotezi reddedilmiştir. 


\subsection{6. Öğrencilerin Sınıfları ile Finansal Okuryazarlık Düzeyleri Arasındaki İlişki} Öğrencilerin finansal okuryazarlık düzeylerinin sınıflarına göre farklılık gösterip göstermediği ve farklılığın anlamlı olup olmadığının tespiti için ANOVA testi uygulanmış ve test sonuçları tablo 9 ve 10 'da gösterilmiştir.

Tablo 9. Sınıf Değişkenine Göre Finansal Okuryazarlık Düzeylerine İlişkin Betimsel İstatistikler

\begin{tabular}{cccc}
\hline Sinıflar & N & $\overline{\mathbf{X}}$ & s.s \\
\hline 1.sinif & 32 & 46,8125 & 14,29513 \\
2.sinif & 64 & 50,0781 & 10,58196 \\
3. sinif & 97 & 53,4021 & 11,93180 \\
4.sinif & 72 & 57,1528 & 11,82937 \\
Toplam & $\mathbf{2 6 5}$ & $\mathbf{5 2 , 8 2 2 6}$ & $\mathbf{1 2 , 3 1 1 1 0}$ \\
\hline
\end{tabular}

$\mathrm{N}=$ gözlem sayısı, $\overline{\mathrm{X}}=$ ortalama, s.s. $=$ standart sapma

Tablo 9 incelendiğinde, öğrencilerin sınıfları ile ortalamaları arasında doğru orantı olduğu, öğrenim gördükleri sınıfları yükseldikçe finansal okuryazarlık düzeylerinin de yükseldiği görülmektedir. Sınıf değişkenine göre ortaya çıkan bu farklılığın anlamlı bir farklılık olup olmadığının tespiti için yapılan ANOVA testinin sonuçları aşağıdaki tabloda da gösterilmiştir.

Tablo 10. Sınıf Değişkenine Göre Sınıfları ile Finansal Okuryazarlık Düzeyleri Arasındaki İlişkiye İlişkin ANOVA Testi Sonuçları

\begin{tabular}{cccccc}
\hline & Kareler Toplamı & df & Ortalama Kare & F & Sig. \\
\hline Gruplar arasi & 3020,541 & 3 & 1006,847 & 7,104 &, 000 \\
Grup içi & 36992,123 & 261 & 141,732 & \\
Toplam & 40012,664 & 264 & & \\
*p<0,05 & & &
\end{tabular}

Yapılan ANOVA testi sonucunda öğrencilerin finansal okuryazarlık düzeyleri ile öğrenim gördükleri sınıfları arasında istatistiksel olarak anlamlı bir farklılık olduğu tespit edilmiştir $(\mathrm{F}=7,104, \mathrm{p}<0,05)$. Bu farklılığın hangi sınıflar arasında olduğunu tespit etmek için Tukey çoklu karşılaştırma testi yapılmış ve sonuçlar Tablo 11'da gösterilmiștir. 
Tablo 11. Araştırma Grubunun Sınıf Değişsenine Göre Finansal Okuryazarlık Düzeyine İliş̧kin Tukey Testi Karş̧laştırılmasını Gösteren Dă̆ı̆ım

\begin{tabular}{llll}
\hline & Sinıf Değişkenleri & Ortalamalar Farkı & $\mathbf{p}$ \\
\hline \multirow{3}{*}{ 1.Sınıf } & 2. Sinıf & $-3,26563$ &, 585 \\
\cline { 2 - 4 } & 3. Sinıf & $-6,58956^{*}$ &, $035^{*}$ \\
\cline { 2 - 4 } & 4. Sinıf & $-10,34028^{*}$ &, $000^{*}$ \\
\hline \multirow{3}{*}{ 3.Sinıf } & 1. Sinıf & 3,26563 &, 585 \\
\cline { 2 - 4 } & 3. Sinıf & $-3,32394$ &, 308 \\
\cline { 2 - 4 } & 4. Sinıf & $-7,07465^{*}$ &, $004^{*}$ \\
\hline \multirow{3}{*}{ 4.Sinıf } & 1. Sinıf & $6,58956^{*}$ &, 035 \\
\cline { 2 - 4 } & 2. Sinıf & 3,32394 &, 308 \\
\cline { 2 - 4 } & 4. Sinıf & $-3,75072$ &, 000 \\
\hline
\end{tabular}

${ }^{*} \mathrm{p}<0,05$

Tablo 11 incelendiğinde, 1.sınıflar ile 3.ve 4.sınıflar arasında anlamlı bir farklilık olduğu, 2.sınıfların sadece 4.sınıflar ile anlamlı olarak farklılaştığı ve 4.sınıfların 1.ve 2.sınıflardan anlamlı olarak farklılaştığ tespit edilmiştir. Bu sonuçlara göre "H4. Öğrencilerin ögrenim gördükleri sınıf ile finansal okuryazarlık düzeyleri arasında anlamlı bir ilişki vardır." hipotezi kabul edilmiştir.

\subsection{7. Öğrencilerin İnternet Bankacılığı Kullanmaları ile Finansal Okuryazarlık Düzeyleri Arasındaki İlişkinin İncelenmesi}

Öğrencilerin internet bankacılığı kullanmaları ile finansal okuryazarlık düzeyleri arasında anlamlı bir ilişkinin olup olmadığı Bağımsız Örneklem t Testi ile kontrol edilmiştir. Tablo 12'de t testinin sonucu gösterilmiştir.

Tablo 12. İnternet Bankacılığı Kullanma ile Finansal Okuryazarlık Düzeyleri Arasındaki İlişkiye İlişkin t Testi Sonuçları

\begin{tabular}{|c|c|c|c|c|c|c|c|}
\hline Hipotez & $\begin{array}{c}\text { İnternet Bankacilığı } \\
\text { Kullanma }\end{array}$ & $\mathbf{N}$ & $\overline{\mathbf{X}}$ & S.S & $\mathbf{t}$ & $\mathbf{p}^{*}$ & $\begin{array}{l}\text { Hipotez } \\
\text { Sonucu }\end{array}$ \\
\hline \multirow{2}{*}{ H1 } & Evet & 226 & 54 & 12,20 & \multirow{2}{*}{1,71} & \multirow{2}{*}{0,04} & \multirow{2}{*}{ KABUL } \\
\hline & Hayır & 39 & 49 & 12,64 & & & \\
\hline
\end{tabular}


Tablo 12 incelendiğinde internet bankacılığı kullanan öğrencilerin ortalamalarının kullanmayan öğrencilere göre daha yüksektir. $\mathrm{Bu}$ farklılık, bağımsız örneklem $\mathrm{t}$ testi sonuçlarına istatistiksel açıdan anlamlı olduğu $(\mathrm{p}<0,05)$ görülmektedir. Buna göre " $H 5$. Internet bankacılı̆̆ kullanan ögrenciler ile kullanmayan ögrencilerin finansal okuryazarlık düzeyleri arasında anlamlı bir ilişki vardır" hipotezi kabul edilmiştir.

\subsection{8. Öğrencilerin Bireysel Emeklilik Sistemine Kayıtlı Olmaları ile Finansal Okuryazarık Düzeyleri Arasındaki İlişkinin İncelenmesi}

Öğrencilerin bireysel emeklilik sistemine kayıtlı olmaları, kredi kartı ve internet bankacılığı kullanmaları ile finansal okuryazarlık düzeyleri arasında anlamlı bir ilişkinin olup olmadığ 1 Bağımsız Örneklem t Testi ile kontrol edilmiştir. Tablo 13'de $\mathrm{t}$ testinin sonucu gösterilmiştir.

Tablo 13. Bireysel Emeklilik Sistemine Kayıtlı Olma ile Finansal Okuryazarlık Düzeyleri Arasındaki İlişkiye İlişkin t Testi Sonuçları

\begin{tabular}{|c|c|c|c|c|c|c|c|}
\hline Hipotez & $\begin{array}{c}\text { Bireysel } \\
\text { Emeklilik } \\
\text { Sistemi }\end{array}$ & $\mathbf{N}$ & $\overline{\mathbf{X}}$ & S.S & $\mathbf{t}$ & $\mathbf{p}^{*}$ & $\begin{array}{l}\text { Hipotez } \\
\text { Sonucu }\end{array}$ \\
\hline \multirow{2}{*}{ H6 } & Evet & 31 & 54 & 13,97 & \multirow{2}{*}{0,575} & \multirow{2}{*}{0,566} & \multirow{2}{*}{ RED } \\
\hline & Hayır & 233 & 53 & 12,12 & & & \\
\hline
\end{tabular}

Tablo 13 incelendiğinde, bireysel emeklilik sistemine kayıtlı olanların ortalamaları kayıtlı olmayanlara göre daha yüksek olmasına rağmen bu farklılığın istatistiksel açıdan anlamlı olmadığ $(\mathrm{p}>0,05)$ görülmektedir. Buna göre "H6. Bireysel emeklilik sistemine kayltlı öğrenciler ile kayıtlı olmayan ögrencilerin finansal okuryazarlık düzeyleri arasında anlamlı bir ilişki vardır" hipotezi reddedilmiştir.

\subsection{9. Öğrencilerin Kredi Kartı ile Finansal Okuryazarlık Düzeyleri Arasındaki İlişkinin İncelenmesi}

Öğrencilerin kredi kartı kullanmaları ile finansal okuryazarlık düzeyleri arasında anlamlı bir ilişkinin olup olmadığı Bağımsız Örneklem $t$ Testi ile kontrol edilmiştir. Tablo 14 'de $\mathrm{t}$ testinin sonucu gösterilmiştir.

Tablo 14. Kredi Kartı Kullanma ile Finansal Okuryazarlık Düzeyleri Arasındaki İlişkiye İlişkin t Testi Sonuçları

\begin{tabular}{|c|c|c|c|c|c|c|c|}
\hline Hipotez & $\begin{array}{c}\text { Kredi Kartı } \\
\text { Kullanma }\end{array}$ & $\mathbf{N}$ & $\overline{\mathbf{X}}$ & S.S & $\mathbf{t}$ & p* & $\begin{array}{l}\text { Hipotez } \\
\text { Sonucu }\end{array}$ \\
\hline \multirow{2}{*}{$\mathrm{H} 7$} & Evet & 160 & 54 & 12,29 & \multirow{2}{*}{1,23} & \multirow{2}{*}{0,218} & \multirow{2}{*}{ RED } \\
\hline & Hayır & 104 & 52 & 12,35 & & & \\
\hline
\end{tabular}


Tablo 14 incelendiğinde kredi kartı kullanan öğrencilerin ortalamaları kullanmayanlara göre daha yüksek olmasına rağmen bu farklılığın istatistiksel açıdan anlamlı olmadığ $1 \quad(\mathrm{p}>0,05)$ görülmektedir. Buna göre "H7. Kredi Kartı Kullanan ögrrenciler ile kullanmayan ögrencilerin finansal okuryazarlı düzeyleri arasında anlamlı bir ilişki vardır" hipotezi reddedilmiştir.

\section{SONUÇ VE TARTIŞMA}

Finansal okuryazarlık, özellikle 2008 yllında başlayan küresel ekonomik kriz ile birlikte dünya genelinde daha fazla gündeme gelmiş ve finansal okuryazarlık düzeyinin artıılmasının önemi daha fazla vurgulanmıştır. Üniversite öğrencilerinin finansal okuryazarlık düzeyinin belirlenmesine yönelik ol bu araştırma Siirt Üniversitesi İktisadi ve İdari Bilimler Fakültesi öğrencileri üzerinde yapılmıştır. Araştırmada öğrencilerin genel finansal okuryazarlık düzeyleri ile alt bileşenleri olan; temel ekonomi ve finans, bireysel bankacıllk, emeklilik ve sigortacilık, finansal tablolar, yatırım, vergi ve mevzuat alanlarında başarı düzeyleri belirlenmiştir. Ayrıca öğrencilerin finansal okuryazarlık düzeylerinin demografik özelliklerine göre farklılık gösterip göstermediği test edilmiştir. Araştırma kapsamında elde edilen verilere frekans, bağımsız örneklem $t$ testi ve Anova testi uygulanmıştır.

Araştırma sonucunda öğrencilerin genel seviyesi 100 üzerinden 53 olarak hesaplanmıştır. Bu sonuç, Kılıç vd, (2015) tarafından aynı anket soruları ile yapılan çalışmada ortaya çıkan sonuca göre (\%48) daha yüksek bir düzeyi göstermektedir. Öğrencilerin en başarılı oldukları alanlar finansal tablolar (65) ile temel ekonomi ve finans (61) alanı iken, en zayıf oldukları alt alanlar matematik ve faiz (39) ile yatırım (41) alt alanları olduğu görülmektedir. Özellikle matematik ve faiz alanında düzeyin düşüklüğü literatürdeki birçok çalı̧̧mayla uyumludur (Örn: Kılıç vd, 2015, Klapper ve Panos, 2013). Bu sonuçlar literatürde yer alan finansal okuryazarlık araştırmalarına benzerlik göstermektedir. Erkek ve kadın ögrencilerin finansal okuryazarlık düzeyleri arasında istatistiksel olarak anlamlı bir farklılık bulunmamıştır. Bu sonuç literatürdeki bazı çalışmaların sonuçlarına uygunken (Örn: Ergün vd, 2015), bazı çalı̧̧malardan da farklılık göstermektedir (Örn: Kılıç vd, 2015; Chen ve Volpe 2002). Öğrencilerin yaşlarına göre finansal okuryazarlık düzeylerinin farklılaştığı, yaşları arttıkça finansal okuryazarlık düzeylerinin de arttığı tespit edilmiştir. Ayrıca öğrencilerin öğrenim gördükleri bölümlere göre finansal okuryazarlık düzeylerinde anlamlı bir farklılık bulunmazken, sınıflar bazında anlamlı bir farklılık tespit edilmiş, sınıfları yükseldikçe finansal okuryazarlık düzeylerinin de yükseldiği tespit edilmiştir. Buna göre, öğrencilerin öğrenim hayatları boyunca edindikleri bilgilerin finansal okuryazarlık düzeylerini artırdığı söylenebilir. İnternet bankacıllğını kullanan öğrencilerin finansal okuryazarlık düzeylerinin, kullanmayan öğrencilere göre anlamlı bir şekilde daha yüksek olduğu tespit edilmiştir. Ancak kredi kartı kullanan öğrencilerin kullanmayanlara göre ve bireysel emeklilik sistemine kayıtlı öğrencilerin kayıtlı olmayan öğrencilere göre finansal okuryazarlık düzeyleri arasında anlamlı bir farklılık tespit edilmemiştir.

Sonuç olarak öğrencilerin orta düzeyde finansal okuryazarlık düzeyine sahip oldukları; yaş, sınıf ve internet bankacıllğı değişkenlerine göre gruplar arasında anlamlı farklılıklar olduğu ve diğer demografik özelliklerine göre katılımcıların finansal okuryazarlık düzeylerinde bir farklılık olmadığı söylenebilir. Araştırmanın sadece İIBF öğrencilerine yönelik olması ve bölümlerdeki tüm öğrencilere ulaşılamaması çalışmanın kısıtlarındandır. 
Üniversitedeki tüm fakültelerde öğrenim gören öğrencilerin finansal okuryazarlık düzeylerinin belirlenmesi ve fakülteler bazında karşılaştırmalı analizlerin yapılması başka bir çalışmanın konusu olabilir.

\section{KAYNAKLAR}

Alkaya, Aylin.- Yağlı, İbrahim (2015), "Finansal Okuryazarlık-Finansal Bilgi, Davranış ve Tutum: Nevşehir Hacı Bektaş Veli Üniversitesi İ̈BF Öğrencileri Üzerine Bir Uygulama", Uluslararası Sosyal Araştırmalar Dergisi, C:8 (40), ss.585-599.

Almenberg, Johan. - Soderberg, Jenny (2011), "Financial Literacy and Retirement Planning in Sweden, Network for Studies on Pnesions, Ageing and Retirement Discussion Papers," V: 112, pp.1-28.

Bayram, Seliha (2014), "Finansal Okuryazarlık ve Para Yönetimi Davranışları: Anadolu Üniversitesi Öğrencileri Üzerine Uygulama”, Uluslararası İşletme ve Yönetim Dergisi C.2(2), ss.105-135.

Baysa, Eray. - Karaca, Sülayman (2016), "Finansal Okuryazarlık ve Banka Müşteri Segmentasyonları Üzerine Bir Uygulama", Muhasebe ve Finansman Dergisi, Temmuz say1s1, ss. 109- 126.

Beal, Diana. - Sarath Delpachitra (2002), "Financial Literacy among Australian University Students", Economic Papers: a Journal of Applied Economics and Policy, V:22 (1), pp.65-78.

Chen, Haiyang. - Ronald P. Volpe (2002), "Gender Differences in Personal Financial Literacy Among College Students”, Financial Services Review, V:11(3), pp.289-307.

Cole, Shawn - Thomas Sampson. - Bilal Z.(2008), "Money or Knowledge? What Drives The Demand for Financial Services in Developing Countries?", Harvard Business School Working Paper, No. 09-117, pp.1-51.

Çoşkun, Selin (2016), "Üniversite Öğrencilerinin Finansal Davranış Ve Tutumlarının Belirlenmesi: Finansal Okuryazarlık Algıları Üzerine Bir Araştırma”, İnsan ve Toplum Bilimleri Araştırmaları Dergisi, C: 5(7), ss. 2257-2258.

Danes, Sharon M. - Tahira K. Hira (1987), "Money Management Knowledge of College Students", The Journal of Student Financial Aid, V:17, pp. 4-16.

Danışman, Emre. - Sezer, Durmuş. - Gümüş, Umut (2016). "Finansal Okuryazarlık Düzeyinin Belirlenmesi: Üniversite Öğrencileri Üzerine Bir Araştırma”, Kara Harp Okulu Bilim Dergisi, C: 26 (2), ss.1-37.

Dilek, Serkan - Küçük, Orhan. - Eleren, Ali (2016), "Kastamonu Üniversitesi Öğrencilerinin Ekonomi Okuryazarlığı”, İnsan ve Toplum Bilimleri Araştırma Dergisi, C:5 (7), ss. 1865-1878. 
Duca, John. - Kumar, Anil (2014), "Financial Literacy and Morgage Equity Withdrawals, Journal of Urban Economics", V:80, pp. 62-75.

Elmas, Bekir. - Yılmaz, Hakan (2016), "Finansal Okuryazarlık: Ağrı İbrahim Çeçen Üniversitesi İktisadi ve İdari Bilimler Fakültesi Öğrencileri Üzerine Bir Çalışma", Ağrı İbrahim Çeçen Üniversitesi Sosyal Bilimler Enstitüsü Dergisi, C:2(2), ss.117140 .

Er, Fikret, - Temizel, Fatih. - Özdemir, Ali. Sönmez, Harun (2014), "Lisans Eğitim Programlarının Finansal Okuryazarlık Düzeyine Etkisinin Araştırılması: Türkiye Örneği”, Anadolu Üniversitesi Sosyal Bilimler Dergisi, ss.113-125.

Ergün, Bahadır - Şahin, Arzu. - Ergin, Erhan (2015), "Finansal Okuryazarlık: İşletme Bölümü Öğrencileri Üzerine Bir Çalışma”, Uluslararası Sosyal Aratırmalar Dergisi, C:7(34), ss.847-864.

Ertürk, Elvan. - Demir, Yusuf (2015), "Finansal Okuryazarlık ve Para Yönetimi: Süleyman Demirel Üniversitesi Akademik Personel Üzerine Bir Uygulama", Muhasebe ve Finansman Dergisi, Ekim say1s1, ss.113-134.

Fettahoğlu, Sibel (2015), "Hane Halkının Finans Eğitimi ve Finansal Okuryazarlık Düzeyleri Üzerine Kocaeli'nde Bir Araştırma”, Muhasebe ve Finansman Dergisi, Temmuz Say1s1, ss.101-116.

Gutnu, Mehmet. - Cihangir, Mehmet (2015), “Finansal Okuryazarlık: Osmaniye Korkut Ata Üniversitesi Personeli Üzerine Bir Araştırma”, Akademik Sosyal Araştırmalar Dergisi, C: $3(10)$, ss. $415-424$.

Güler, Emine. - Tunahan, Hakan (2017), "Finansal Okuryazarlık: Hane halk1 Üzerine Bir Araştırma", Sakarya Üniversitesi İşletme Bilimi Dergisi, C:5(3), ss.79-104.

Hogart, Jeanne M. (2002). "Financial Literacy and Family and Consumer Sciences, Journal of Family and Consumer Sciences". V:94, pp.15-28.

Kılıç, Yunus - Ata, Ali. - Seyrek, İbrahim (2015), "Finansal Okuryazarlık: Üniversite Öğrencilerine Yönelik Bir Araştırma”, Muhasebe ve Finansman Dergisi, Nissan Sayıs1, ss.129-150.

Klapper, Leora .- Panos Georgias (2013), "Financial Literacy and Retirement Planning: the Russian Case", Journal of Pension Economics and Finance, V: 40 (4), pp.599-618.

Köseoğlu Mustafa, -Yamak Rahmi (2002), Uygulamalı İstatistik, Derya Kitabevi, Trabzon

Lusardi, Annamaria (2008). "Financial Literacy: An Essential Tool for Informed Consumer Choice", Joint Center for Housing Studies of Harvard University, pp.1-26.

Lusardi, Annamaria. - Olivia Mitchell (2007), "Baby Boomer Retirement Security: The Roles of Planning", Financial Literacy, and Housing Wealth, Journal of Monetary Economics, V:54, pp.205-224 
Markovic, Charli A. - Sharon A. Devaney (1997), “College Seniors' Personal Finance Knowledge and Practices", Journal of Family and Consumer Sciences, V:89, pp.6165.

Rooij, Maarten V. - Annamaria, Lusardi. - Rob, Alessie (2011), "Financial Literacy and Stock Market Participation”, DNB Bank Working Paper, No: 13565, pp.1-50.

Özdamar Kazım (2004), Paket Programlar İle İstatistiksel Veri Analizi, Kaan Kitabevi.

Sarı̈ül, Haşmet (2014), “A Survey of Financial Literacy Among University Students”, Muhasebe ve Finansman Dergisi, Ekim sayıs1, ss.207-224.

Şamiloğlu, Famil. - Kahraman, Yunus. - Bağcı, Haşim (2016), "Finansal Okuryazarlık Araştırması: Erciyes Üniversitesi Öğrencileri Üzerinde Bir Uygulama”, Uluslararası Yönetim İktisat ve İşletme Dergisi, ICAFR 16 Özel Sayısı, ss. 308- 318.

Tamimi, Al. - Al Bin Kalli (2009), "Financial Literacy and Investment Decisions of UAE Investors, Journal of Risk Finance", V:10 (5), pp.500-516.

Tuna, Gülfen - Ulu, Mehmet (2016), “Üniversite Öğrencilerinin Finansal Okuryazarlık Düzeylerini Etkileyen Faktörlerin Belirlenmesi: İşletme Bölümü Öğrencileri Üzerine Bir Araştırma", Uluslararası Yönetim İktisat ve İşletme Dergisi, ICAFR 16 Özel Say1s1, ss.128-141.

Worthington, Andrew C. (2006), "Predicting Financial Literacy in Australia", Financial Services Review, V:15(1), pp.59-79. 


\section{EK 1: ANKET FORMU}

Değerli katılımc1,

$\mathrm{Bu}$ anket çalışması, üniversite öğrencilerinin finansal okuryazarlık düzeylerinin belirlenmesi amacıyla hazırlanmıştır. Sorulara verilen cevaplar bilimsel amaçlarla değerlendirilecektir. Araştırmanın geçerliliği açısından bütün soruların cevaplanması önem arz etmektedir. Lütfen seçenekler arasından size göre en doğru olanı işaretleyiniz.

\section{Cevaplarınız kesinlikle gizli tutulacaktır.}

\section{Katılımınız için teşekkür ederiz.}

\begin{tabular}{|c|c|c|c|c|}
\hline & Temel Düzeyde Ekonomi ve Finans & Doğru & Yanlış & $\begin{array}{c}\text { Fikrim } \\
\text { Yok }\end{array}$ \\
\hline 1 & Enflasyon paranın satın alma gücünü azaltır. & & & \\
\hline 2 & Türkiye'de enflasyon oranları \%10'un altındadır. & & & \\
\hline 3 & Enflasyon oranı piyasadaki kredi faiz oranından yüksek ise kredi kullanmak avantajlıdır. & & & \\
\hline 4 & $\begin{array}{l}\text { Bir evi kiralamak, ev satın almaya kıyasla finansal açıdan bütçenizi daha rahat } \\
\text { kullanmanızı sağlar. }\end{array}$ & & & \\
\hline 5 & Borsalarda sadece hisse senedi alım-satımı yapılmaktadır. & & & \\
\hline 6 & Türkiye'deki menkul kıymetler borsasının adı Borsa İstanbul'dur. & & & \\
\hline 7 & Vadesiz mevduat hesabı faiz kazancı sağlar. & & & \\
\hline \multirow[t]{2}{*}{8} & Ons, altın gibi kıymetli madenlerin ölçü birimidir. & & & \\
\hline & Bireysel Bankacılık & Doğru & Yanlış & $\begin{array}{c}\text { Fikrim } \\
\text { yok }\end{array}$ \\
\hline 9 & Tüm bankalar aynı işlem ücretleri ile çalışırlar. & & & \\
\hline 10 & Uzun vadeli kredi kullanmak kısa vadeli kredi kullanmaktan daha maliyetlidir. & & & \\
\hline 11 & IBAN, uluslararası banka hesap numarasıdır. & & & \\
\hline 12 & EFT, aynı bankadaki hesaplar arasında para transferi yapmak için kullanılır. & & & \\
\hline 13 & İnternet bankacılığı yardımıyla kredi başvurusu yapılabilmektedir. & & & \\
\hline \multirow[t]{2}{*}{14} & İnternet bankacılığı yardımıyla hisse senedi alım satım işlemleri yapılabilmektedir. & & & \\
\hline & Emeklilik ve Sigortacılık & Doğru & Yanlış & $\begin{array}{c}\text { Fikrim } \\
\text { yok }\end{array}$ \\
\hline 15 & Bireyin yaşı, araç kasko bedelinin belirlenmesinde önemli bir rol faktördür. & & & \\
\hline 16 & $\begin{array}{l}\text { SGK (Sosyal Güvenlik Kurumu), Türkiye'de çalışanların bağlı oldukları sağlık güvencesi } \\
\text { kurumudur. }\end{array}$ & & & \\
\hline 17 & Türkiye'de emeklilik yaşı herkes için 65 'tir. & & & \\
\hline 18 & Bireysel emeklilik sistemi, aylık prim ödemeleri yapılan özel bir emeklilik sistemidir. & & & \\
\hline \multirow[t]{2}{*}{19} & $\begin{array}{l}\text { Bireysel emeklilik sisteminde emekliliğe hak kazanmak için } 10 \text { yıl süreyle katk1 pay1 } \\
\text { ödemesi yapmak gerekmektedir. }\end{array}$ & & & \\
\hline & Finansal Tablolar & Doğru & Yanlış & $\begin{array}{c}\text { Fikrim } \\
\text { yok }\end{array}$ \\
\hline 20 & Bilanço, belirli bir tarihteki varlıkları, borçları ve özsermayeyi gösterir. & & & \\
\hline 21 & Öz sermaye, toplam varlıklarla borçlar arasındaki farktır. & & & \\
\hline
\end{tabular}


22 Eğer bir bireyin öz sermaye hesabında $9.000 \mathrm{TL}$ ve borç hesabında $8.000 \mathrm{TL}$ varsa bu bireyin toplam varlıklar1 17.000 TL'dir.

23 Nakit sıkıntısı çeken bir şirket, kesinlikle zarar etmiştir.

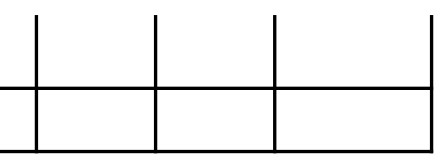

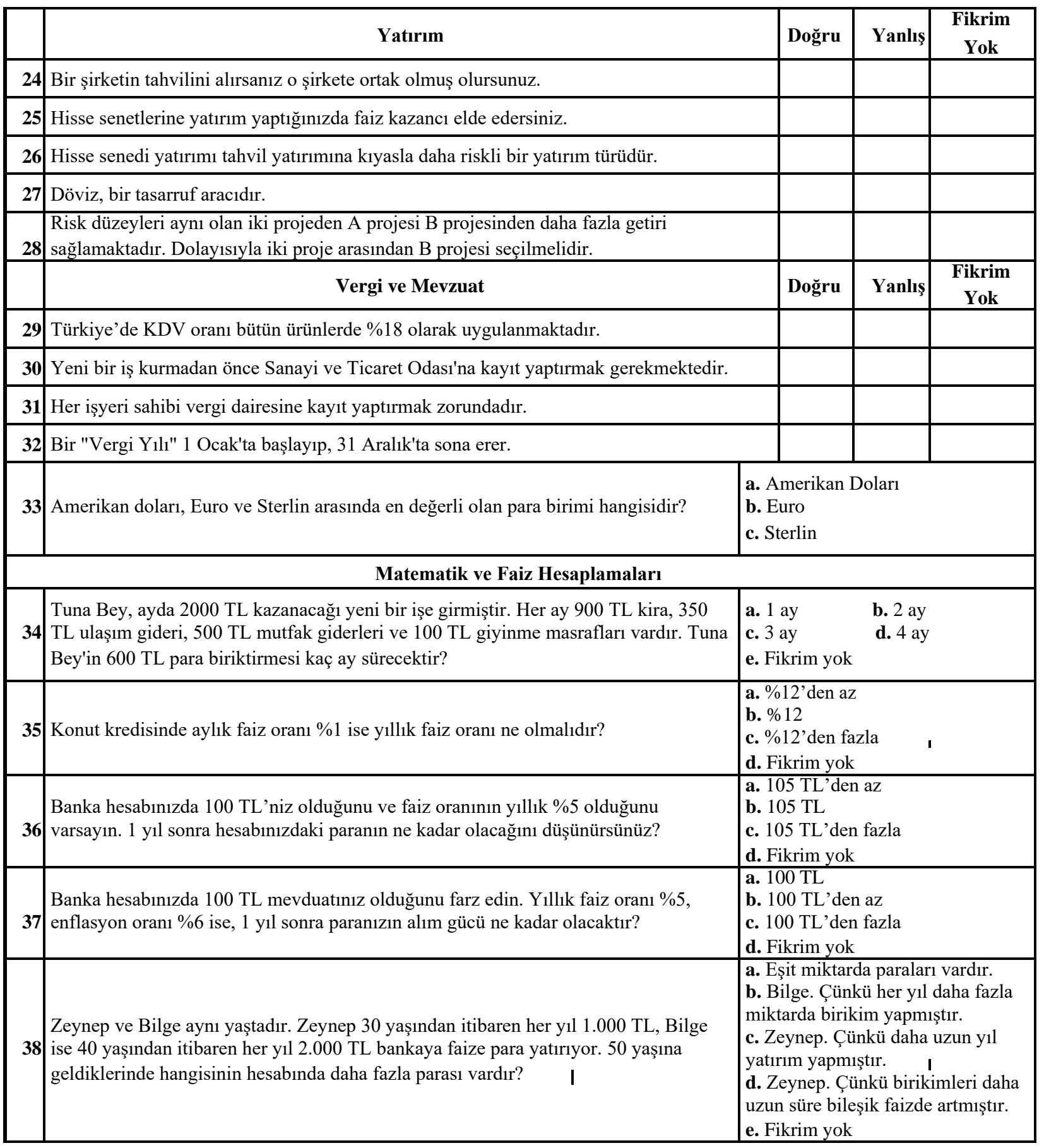

\begin{tabular}{|l|l|}
\hline Cinsiyetiniz & ( ) Erkek ( ) Kadın \\
\hline Yaşınız & \\
\hline Bölümünüz & \\
\hline SInıfınız & \\
\hline Öğretim türünüz & ( ) Örgün öğretim $\quad$ ( ) İkinci öğretim \\
\hline
\end{tabular}




\begin{tabular}{|l|l|} 
Babanızın eğitim durumu & $\begin{array}{l}\text { ( ) Okuryazar değil ( ) Okuryazar( ) İlköğretim () Lise } \\
\text { () Üniversite ( )Lisansüstü }\end{array}$ \\
\hline Annenizin eğitim durumu & $\begin{array}{l}\text { ( ) Okuryazar değil ( ) Okuryazar ( ) İlköğretim ( ) Lise } \\
\text { ( ) Üniversite ( )Lisansüstü }\end{array}$ \\
\hline Kredi kartı kullanıyor musunuz? & ( ) Evet ( ) Hayır \\
\hline Bireysel emeklilik sistemine katılımınız var mı? & ( ) Evet () Hayır \\
\hline İnternet bankacılı̆ı kullanıyor musunuz? & ( ) Evet ( ) Hayır \\
\hline
\end{tabular}

